\title{
Pelatihan Strategi Pemasaran Di Era New Normal Pada Kalangan Mahasiswa Fakultas Ekonomi Dan Bisnis Universitas Bumigora
}

\author{
Rini Anggriani ${ }^{1}$, Abdurrahman ${ }^{2}$, Isra Dewi Kuntary lbrahim ${ }^{3}$, \\ rinianggriani@universitasbumigora.ac.id ${ }^{1}$, \\ abdurrahman@universitasbumigora.ac.id ${ }^{2}$, israibrahim@universitasbumigora.ac.id ${ }^{3}$ \\ 1,2,3 Universitas Bumigora
}

\begin{abstract}
Article History:
Received: 08-01-2021

Accepted: 28-01-2021
\end{abstract}

\begin{abstract}
The purpose of this training is to increase the knowledge of students during "new normal" era through training on sustainable marketing strategies. They are expected to survive and to produce product or service competitiveness that is able to compete in competitive competition. In addition, training is carried out to provide added value and increases various marketing mixed strategies which include 4P's (Product, Place, Price and Promotion).

The method of implementing this service program is carried out by early identification of students who are related to the problems and obstacles faced by students. Therefore, both parties carry out the program by three steps which are preparation of materials, training or socialization, and recommendations.
\end{abstract}

Keywords: Entrepreneurship, Marketing Strategy, New Normal Era, Students of the Faculty of Economics and Business.

\section{Pendahuluan}

Tidak bisa dipungkiri, dampak pandemi saat ini menimbulkan berbagai persoalan sosial baru yang melanda masyarakat khususnya kalangan mahasiswa. Efek dari pandemi beberapa waktu yang lalu yang memberlakukan Work From Home (WFH) sehingga tidak sedikit perusahaan yang terpaksa menghentikan operasionalnya bahkan gulung tikar. Imbasnya, tingkat kehilangan pekerjaan produktif melonjak drastis sehingga berdampak pada keberlangsungan hidup kedepan. Berdasarkan hasil wawancara awal, alasan kenapa mahasiswa memutuskan berwirausaha, mereka mengaku orang tuanya terpaksa dirumahkan, kondisi ekonomi keluarga semakin tidak stabil dan mereka terancam terkendala biaya yang berpotensi pada kemungkinan putus kuliah ditenggah jalan. Namun, dengan berwirausaha mereka merasa dapat meringankan beban orang tua dan mencari biaya tambahan guna tetap melanjutkan kuliah. Menurut llyas, et,. al. (2020) keinginan berwirausaha para mahasiswa merupakan sumber bagi lahirnya wirausaha-wirausaha masa depan.

Mahasiswa Fakultas Ekonomi dan Bisnis (FEB) Program Studi Manajemen dan Akuntansi merupakan pelaku bisnis pemula yang masih harus dibina dan diarahkan agar tetap survive bukan hanya sebagai berwirausaha "sesaat" seumuran jagung semata. Hal ini 
disadari betul bahwa mahasiswa sebagai garda terdepan generasi masa depan bangsa harus mampu berpikir kretif dan inovatif mampu mandiri dengan membuka lahan kerja baru sehingga berkontribusi pada pembangunan nasional sesuai dengan misi pemerintah meningkatkan talenta calon wirausaha muda di Indonesia. Untuk itu memberikan pelatihan strategi pemasaran sangat penting bagi mahasiswa pemula guna menghasilkan wirausaha produktif yang memiliki daya saing yang patut diperhitungkan.

Masalah yang dihadapi mitra saat ini adalah 1) Kurangnya pengetahuan dan pemahaman mitra tentang bagaimana strategi pemasaran yang efektif dalam meraih konsumen ditengah sengitnya persaingan dan kondisi ekonomi yang terpuruk. 2) Dampak dari pandemi menyebabkan banyak pegawai yang dirumahkan dan beralih menjadi penjual dadakan sehingga hal ini meningkatkan persaingan usaha. 3) Adanya persaingan yang sengit tersebut menuntut mitra melakukan inovasi dan mengetahui strategi pemasaran yang efektif dalam menarik konsumen. Menurut Kotler, (2013) strategi pemasaran logika pemasaran dimana pelaku usaha berharap untuk menciptakan nilai dan memperoleh keuntungan dari hubungannya dengan konsumen. Menurut Swastha, (2014) strategi pemasaran adalah suatu sistem keseluruhan dari kegiatan-kegiatan bisnis yang ditujukan untuk merencanakan, menentukan harga, mempromosikan, dan mendistribusikan barang dan jasa yang memuaskan kebutuhan baik kepada pembeli yang ada maupun pembeli potensial.

Sementara menurut Wibowo, et.,al. (2015) strategi pemasaran adalah salah satu cara memenangkan persaingan keunggulan bersaing yang berkesinambungan baik itu untuk perusahaan yang memproduksi barang atau jasa. Kegiatan kewirausahaan merupakan kegiatan usaha yang mampu memperluas lapangan kerja, memberikan pelayanan ekonomi secara luas kepada masyarakat, peningkatan pendapatan dan mendorong pertumbuhan ekonomi dan berperan dalam mewujudkan stabilitas nasional (Wibowo et al., 2015). Sedangkan menurut Riyanto, (2000) mengemukakan pendidikan kewirausahaan merupakan semacam pendidikan yang mengajarkan agar orang mampu menciptakan kegiatan usaha sendiri. Strategi pemasaran adalah alat untuk mencapai tujuan pemasaran yang merupakan suatu cara bagaimana merebut mind share pelanggan (Budiarto, 2013).

\section{Metode}

Sasaran pengabdian ini ditujukan kepada mahasiswa di Fakultas Ekonomi dan Bisnis Universitas Bumigora yang memiliki usaha untuk meningkatkan pengetahuan mahasiswa terkait strategi pemasaran yang efektif dalam meningkatkan daya saing produk/jasa dalam bidang usaha yang digeluti sehingga berimbas pada peningkatan volume penjualan. Sehingga sangat penting bagi mahasiswa sebagai pelaku wirausaha pemula 
untuk dilakukan pelatihan strategi pemasaran. Metode pelaksanaan program dilakukan melalui online dengan aplikasi Google Meet dan Grup WhatAapp. Hal ini dilakukan karena kondisi Pandemi Covid-19 yang tidak memungkinkan untuk memberikan pelatihan secara langsung. Meskipun dilakukan secara online, penyampaian materi dilakukan dengan metode ceramah, komunikasi interaktif antara kedua belah pihak terkait permasalahan yang dihadapi dan solusi alternatif sebagai rekomendasi dalam pemecahan masalah yang dihadapi. Selanjutnya untuk melakukan evaluasi dan pemberian pelatihan yang berkesinambungan.

Berikut tahapan-tahapan pelatihan yang dilakukan adalah:

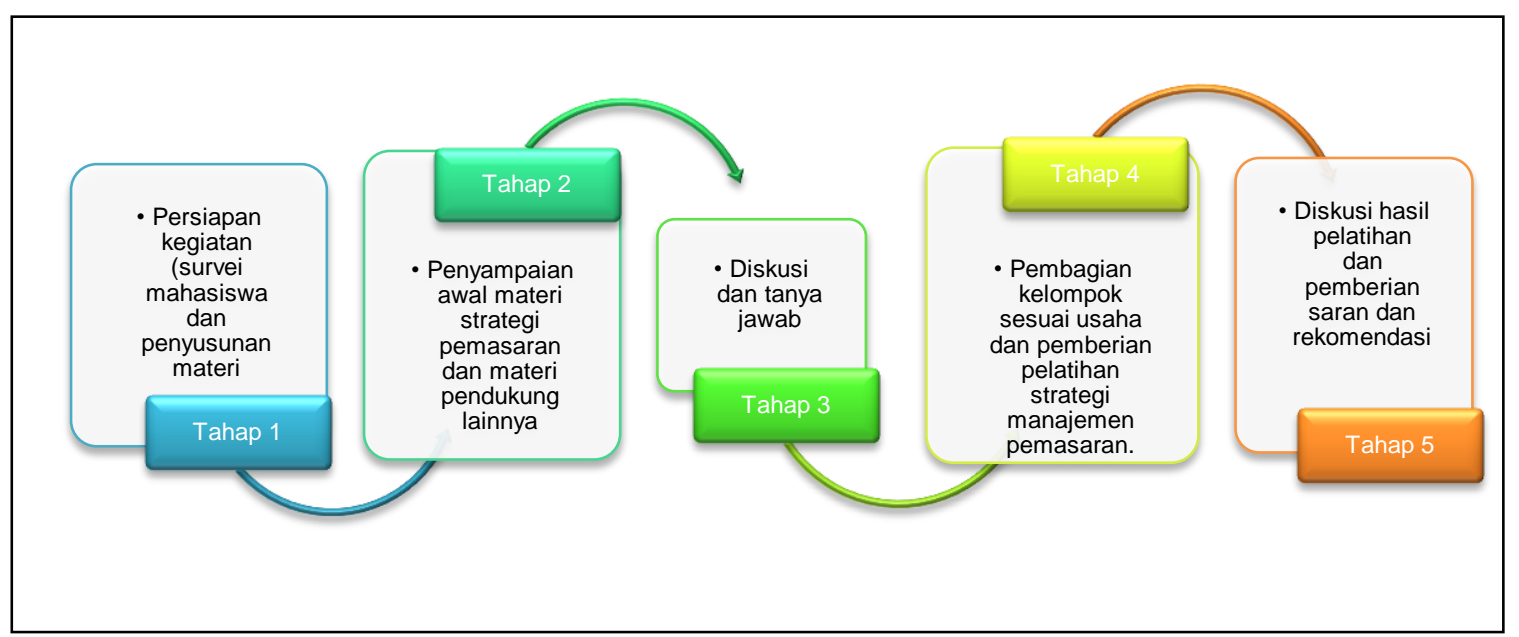

Gambar 1. Tahap-tahap pelatihan

Adapun partisipasi mahasiswa dalam pelaksanaan program pelatihan ini adalah sebagai berikut :

1) Mahasiswa mendapatkan pembekalan materi terkait strategi pemasaran dan materi pendukung lainnya.

2) Dalam sesi diskusi dan tanya jawab, mahasiswa menyampaikan permasalahan dan kendala atas masalah yang dihadapi dan pembicara memberikan respon atau umpan balik.

3) Pembagian kelompok sesuai jenis usaha dan pemberian pelatihan strategi pemasaran yang sesuai dengan jenis usaha dan terjadi diskusi dua arah.

4) Sesi diskusi hasil pelatihan strategi pemasaran oleh semua pihak dan penyampaikan saran dan rekomendasi.

5) Pada sesi ini peserta dalam hal ini mahasiswa mendengarkan penyampaian simpulan akhir dari pemateri dan penutup kegiatan pelatihan.

Agar kegiatan pengabdian ini tetap berkelanjutan dan berkesinambungan diperlukan rencana strategis dan evaluasi pelaksanaan program pemberdayaan melalui pelatihan yang 
rutin dan konsisten hingga pada akhirnya direncanakan membentuk market place sebagai wadah bagi kewirausahaan mahasiswa.

\section{Pembahasan}

Pengabdian ini memberikan pelatihan dan pembekalan materi terkait strategi pemasaran dan materi pendukung untuk meningkatkan pengetahuan kepada mahasiswa. Selain itu, pelatihan ini bertujuan untuk meningkatkan kemampuan mahasiswa dalam mengelola usaha. Menurut Hasibuan, (2016) pelatihan merupakan suatu usaha dalam rangka membina tenaga kerja, yaitu ilmu pengetahuan, keterampilan, dan kemampuan seseorang dalam menjalankan usaha dan tugas-tugasnya. Pelatihan yang dilakukan diharapkan dapat meningkatkan pengetahuan dan kemampuan mahasiswa dalam menjalankan usaha mereka demi keberlanjutan usahanya di era new normal pada pandemi corona virus 2019 (covid-19). Mahasiswa juga diberikan bimbingan khusus selama menjadi mahasiswa aktif di FEB Universitas Bumigora. Berikut tahapan yang dilakukan :

1. Tahap Persiapan Kegiatan

Tim pelaksana mempersiapkan dan menyiapkan kegiatan pelatihan kepada mahasiswa di FEB Universitas Bumigora, kemudian pemateri menyiapkan materi pembahasan mengenai strategi pemasaran yang efektif untuk diterapkan di kondisi new normal.

2. Tahap Penyampaian Materi

Pemateri menjelaskan materi yang telah disiapkan tentang strategi pemasaran kemudian mengistruksikan kepada mahasiswa untuk menyimak dan menyiapkan pertanyaan serta permasalahan-permasalahan selama menjalankan bisnisnya.

3. Tahap Diskusi dan Tanya jawab

Setelah materi disampaikan kemudian peserta pelatihan berdiskusi mengenai studi kasus yang diberikan oleh pemateridan didampingi langsung untuk mengerjakan studi kasus jika partisipan mendapat kesulitan dalam studi kasus tersebut.

4. Tahap Pembagian Kelompok

Pembagian kelompok dilakukan sesuai kriteria usaha agar lebih mudah dalam pembagian tugas dan pendampingan untuk penerapan strategi pemasaran.

5. Tahap Evaluasi Hasil Pelatihan

Peserta pelatihan memahami dan mampu menerapkan strategi marketing yang relevan sesuai kondisi new normal pasca pandemi covid-19, selain itu pemateri memberikan saran serta rekomendasi kepada peserta pelatihan dalam hal ini mahasiswa FEB Universitas Bumigora untuk tetap melakukan terobosan-terobosan baru agar tetap survive dan sustainable dalam bisnis yang dijalankan.

6. Penyampaian Kesimpulan dan Penutup 


\section{ADMA}

Gurnal Pengabdian dan Pemberdayaan Masyarakat
2021, Vol.1, No.2, Hal 91-98

Doi: 10.30812/adma.v1i2.1027

Setelah dilakukan evaluasi terhadap hasil pelatihan yang telah dilaksanakan maka, setiap pemateri memberikan kesimpulan sekaligus penutup pada pelatihan yang sudah berlangsung sesuai tahapan yang direncanakan.

Berikut dokumentasi pembekalan awal materi :

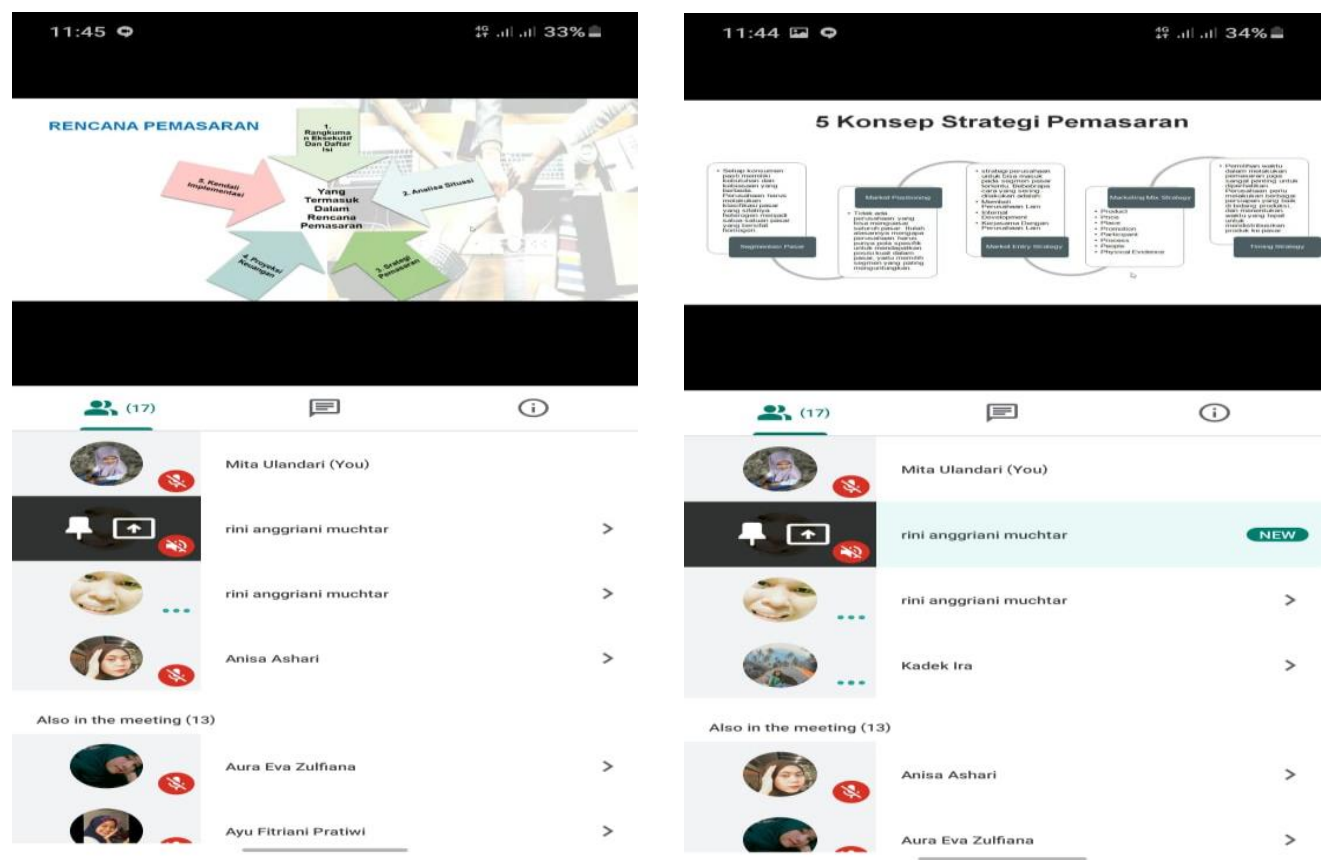

Gambar 2. Dokumentasi paparan konsep materi tentang strategi pemasaran
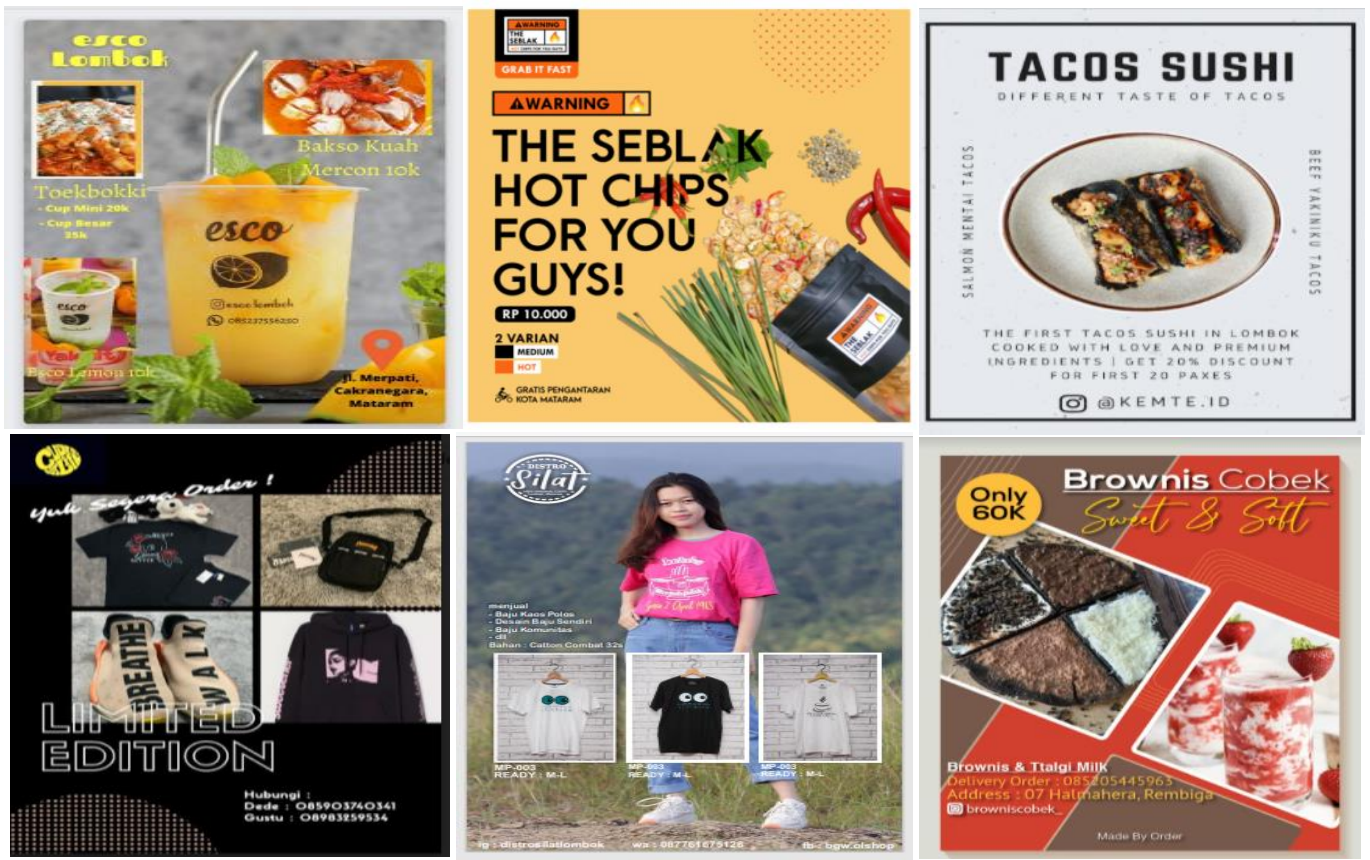

Gambar 3. Dokumentasi hasil desain poster promosi beberapa usaha mahasiswa

Adapun indikator keberhasilan program pengabdian ini adalah diharapkan : 1) Adanya peningkatan pengetahuan dan keterampilan mahasiswa sebagai mitra dalam mendesain dan menerapkan strategi pemasaran yang efektif dan menarik dan 2) Dapat 
meningkatkan motivasi semangat kewirausahaan mahasiswa secara mandiri dan berdaya saing, sehingga mampu membuka lapangan kerja baru dan berkontribusi bagi perekonomian masyarakat.

\section{Kesimpulan}

Hasil kegiatan pengabdian kepada masyarakat dapat disimpulkan sebagai berikut 1) Memberikan wawasan, pengetahuan dan keterampilan dalam pembuatan inovasi produk melalui penerapan materi strategi pemasaran yang efektif dalam menjalankan usaha di era new normal pasca pandemi covid-19. 2) Membantu mitra dalam membuat konten promosi yang kreatif sehingga dapat menarik konsumen serta dapat meningkatkan omset penjualan. 3) Memberikan masukan kepada mitra bagaimana strategi pemasaran yang efektif sehingga dapat menambah engagement dan brand awareness. Selama proses kegiatan ini, antusiasme mitra sangat tinggi.

Hal ini ditunjukan dengan kemampuan mitra memaparkan kendala yang dihadapi. Kegiatan ini memang sudah dilaksanakan sampai dengan tahap pelatihan awal terkait strategi pemasaran. Perlu di ketahui kegiatan ini akan terus dilakukan secara berkelanjutan sebagai upaya pendampingan terhadap mahasiswa sebagai mitra agar usahanya dapat terus bertahan dan menjadi wirausaha yang mandiri dan berdaya saing sehingga mampu menjadi pelopor perubahan dan berkontribusi pada ekonomi masyarakat.

\section{Ucapan Terima kasih}

Terima kasih kami ucapkan kepada Rektor Universitas Bumigora, Kepala Unit Lembaga Penelitian dan Pengabdian Masyarakat, dan lembaga-lembaga terkait. Terima kasih juga kami ucapkan kepada mahasiswa-mahasiswi yang sudah punya kegiatan usaha sebagai mitra, serta ucapan terimakasih juga kami sampaikan kepada sekenap tim dosen dan mahasiswa yang sudah berkontribusi pada kegiatan pengabdian ini. Kami menyadari, bahwa pelaksanaan pengabdian dapat berjalan lancar karena adanya dukungan dari semua pihak. 


\section{Daftar Pustaka}

Budiarto, S. (2013). Strategi Pemasaran dengan Menggunakan Pendekatan Mark Plus \& Co di Kandatel Jakarta. Jurnal Industri Elektro Dan Penerbangan, 3(1), 13-24.

Hasibuan, M. S. P. (2016). Manajemen Sumber Daya Manusia (Edisi Revi). PT. Bumi Aksara, Jakarta.

llyas, M., Anas, A., \& Islamiah, R. Y. (2020). Pengembangan Kewirausahaan Bagi Mahasiswa dan Alumni. (1), 1-12.

Kotler, P. (2013). Marketing Principles (12th ed.). Erlangga.

Riyanto, A. (2000). Teori Konstitusi. Bandung: Yapemdo.

Swastha, Basu, I. (2014). Manajemen Pemasaran Modern. In Liberty, Yogyakarta. https://doi.org/10.1017/CBO9781107415324.004

Wibowo, D. H., Arifin, Z., \& Sunarti. (2015). Analisis Strategi Pemasaran Untuk Meningkatkan Daya Saing UMKM. Jurnal Administrasi Bisnis, 29(1), 59-66. 
